OOPEN ACCESS

International Journal of Applied Research in Social Sciences

P-ISSN: 2706-9176, E-ISSN: 2706-9184

Volume 2, Issue 2, P.No. 41-52, May, 2020

Fair East Publishers

Journal Homepage: www.fepbl.com/index.php/ijarss

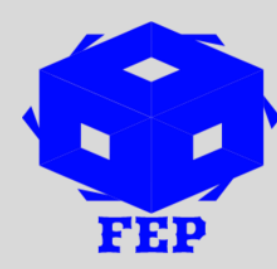

\title{
HASSAN IBN THABIT: AN ORIGINAL ARABIC TONGUE (2)
}

Yahya Saleh Hasan Dahami ${ }^{1}$

${ }^{1}$ Associate Professor, English Department - Faculty of Science and Arts,

AL BAHA UNIVERSITY - KSA

ORCID: https://orcid.org/0000-0003-0195-787

*Corresponding Author: Yahya Saleh Hasan Dahami

${ }^{1}$ Corresponding Author Email: dahami02@gmail.com

Article Received: 10-01-20 Accepted: 21-04-20

Published: 05-05-20

Licensing Details: Author retains the right of this article. The article is distributed under the terms of the Creative Commons Attribution-NonCommercial 4.0 License

(http://www.creativecommons.org/licences/by-nc/4.0/) which permits non-commercial use, reproduction and distribution of the work without further permission provided the original work is attributed as specified on the Journal open access page.

\begin{abstract}
As it is suggested and recommended in the first part of a previous paper that carries the same title, this paper is a continuous effort not to claim to be wide-ranging in mastering a poetic piece as one sort of expressive manuscript in Arabic but an impartial effort through analytical assessment of a poem. The study is limited to a few selected verses of Hassan ibn Thabit poem named 'Al Alef rhymed (قافية الألف).' It is a representative of the Arabic tongue and its magnificence. It is a piece of poetry that cannot be examined and scrutinized in a short paper like this.

The study focuses, with analysis, on six verse lines - 17/22 - of Hassan ibn Thabit's poem mentioned above. It employs an analytical and critical method, makes an effort to illustrate the inspiration of Arabic poetry as a means of the tongue and its grandeur and glory. The study initiates with an introduction raising the importance of Arabic classical poetic tongue. Then it goes go forward to give a picture of Hassan ibn Thabit as a man and a poet. The researcher, then, shifts to the foremost segment of the study, attempting to bring an interpretation to some selected verses of Hassan's above-mentioned long poem. The paper reaches its conclusion by a concise discussion and recommendatory afterword.
\end{abstract}

Keywords: Arabic poetry, Arabic tongue, classical language, Islamic poetry, the poet of the Prophet,

\section{INTRODUCTION}

The Majesty of Arabic Tongue: In his Muqaddimah (Introduction), Ibn Khaldoun (also Khaldūn) highlights that for Arabs, poetry is where splendid deeds, history, erudition, 
experience, and knowledge are gathered. Similarly, it is the central orientation point for sagacity, knowledge, experience, perception, and wisdom. The Arabic tongue is abundant, productive, and fruitful with proverbs, perceptiveness, knowledge, sagacity, sense, insight, and wisdom. To recite Ibn Khaldoun (1958), "(Poetry) in the Arabic language is remarkable in (its) manner and powerful in (its) way" (p. 373). He then carries on to affirm that Arabic poetry is a deep, genuine, pure, and natural illustration of the prototypical of Arab 'virtue' which make a contribution to the Arabic expression (مروة) muruwwa. Equally, the argument is sustained by Gruendler (2002), stating that the "classical Arabic poetry is the literary canon from which medieval Arab linguists, genealogists, and other scholars take evidentiary verses (shawiihid) to support their arguments. In this way, ancient poetry 'judges' many a scholarly case" (p. 257).

Its endless literature of minimum seventeen centuries touches effectively on every theme of human inspiration and undertaking; there is scarcely a subject within the whole range of human attention to which a part of such literature has made no influence. Considering the discipline of history, critics and historians witness that classical Arabic language is the most significant of all languages of the world for a comprehensive history. Furthermore, several others list Arabic as the third among those which have had overwhelming importance as transporters of culture. [The] Arabic language has had the most exceptional growth and broadened of all the languages of the earth and that merely within the last two centuries has the English language come to competing Arabic (Dahami, 2019a).

On top of that, it might be said that the passion for a poetical arrangement, construction, and makeup are fervent and enthusiastic in the Arabic language. Poetry is boundless, unlimited, and never-ending "in number and is transmitted from mouth to mouth. It was of great attraction where all listeners admired them, whatever people were, high or low, rich or poor. Poetry in the Arabic language is full of music and exquisite accent" (Dahami, 2015). With its unending reliance on connotation and sound, poetry plays an indispensable part. As the eminent contemporary Arab poets and versifiers have often backed, poetry might have a leading approach to the transformations ascending in various cultures, civilizations, and societies.

History of the tongue literature as outlined by Al-Hashimi in his encyclopedic volume Jewelry of Literature in Literatures and Growth of the Tongue of Arabs (1969), is that knowledge, science, and learning which searches in the expression of the language and its circumstances, situations and contexts - its style, luxury, approach, prose, and verse - in its countless ages. It is the science that explores and deep dives in its eminent and elevated situation and position, in addition to what happened for its innovators, pioneers, and developers who left a warm influence in it (p. 3). Similarly, he describes the Arabic tongue saying that it is one of the Semitic tongues; it is the ancient mutual, common, popular, and universal tongue of the Arabs nation who resided the peninsula that took its name from them, which is sited to the western border of Asia. Lewis (2002), shares similar notions on the Arabic language indicating that the knowledge, acquaintance, wisdom, sciences were transmitted and conveyed into the Arabic tongue from diverse parts of the world; via the Arabic language, sciences were embellished and infiltrated to the hearts of people, while the 
attractiveness, advantages, beauties, and benefits of that language flowed in their moods and blood vessels (p. 142). Besides, Mou'nis (1978), comments that the untainted and purest representation of the original Semitic that grew, developed, and matured in the Arabian Peninsula is the Arabic tongue which indeed initiated as a complete, exact, and perfect culture; the Arabic language is not a mere means of culture but a tool and culture in concert (p.343). Additionally, Faheem (1986), opines that the Arabic language is the tongue of human knowledge and science (p. 200).

The Arabic language is the language of the Qur'an that honors it. So, the Arabic language remained unchanged. Through statistics estimates, the number of Arabic-speaking is estimated at more than half a billion people around the world, and the number is still rising due to the beauty and elegance of the Arabic language. It has saved Qur'an and saved their bases and alphabet and not changed like the rest of other languages. The Arabic language has been named as the language of Thad (ض) because it is the only language that contains the letter Thad (ض), although Arabs speak the Arabic language, they do not realize the sweetness of its words except in the Koran. The Arabic language has been the focus of attention from the Arabs and foreign scholars, grammarians, and scientists so that they could narrate words and phrases and requirements for it (Dahami, 2018a).

On all occasions, The Arabs of the Desert are people of courage, gallantry, and bravery. Their exploratory mode and manner of life make courage vital. The "Arabic-Muslim-speaking people were the major bearers of the torch of culture, knowledge, and civilization throughout the world" (Dahami, 2015; Hitti, 1989, p.557). Constant wanderers, they roam to and fro looking for the necessary water supply for their living area. They are great horsemen; the Arabs cavalry make their presence from the fourth century. When the sight of encounter is reached, a rider would drop, and mounting the horse he had led, riding without a saddle, to the spot.

It is from Arabia, thenceforward, that Arab poetry was to come; for the nations, lands and realms were profligately engrossed with profitable trade materials, matters, and varieties of stuff to provide and donate literature any possibility of progression and evolution. Seignobos (1912), opines that "Towards Arabia, from which they brought gold, agate, and onyx, incense and myrrh, and the perfumes of Arabia; pearls, spices, ivory, ebony, ostrich plumes and apes from India" (p. 81). Furthermore, Thaif (1960), in History of Arabic Literature: Ignorance Age, points out saying: they do not reach the age of pre-Islam that they talk about until they discover the classical Arabic has been completed and reached the summit of its expansion and growth (p. 121). Additionally, Allen (2000), pronounces that Arabic poetry has always been looked upon as the diwan of Arabs (the fountain or salon of Arabs), a soiree in times of grief and cheerfulness, of downfall and triumph, a set phrase of the Arab people's social, artistic, intellectual, cultural ideals besides high aspirations (pp. 65-66). What is more, "Arabic poetry was limitless in number and is transmitted from mouth to mouth. It was of great attraction where all listeners admired them, whatever people were, high or low, rich or poor. Poetry in the Arabic language is full of music and exquisite accent" (Dahami, 2019b). 
Northwards, cultivation, advancement, and refinement had early prolonged to the Arabian oases. On the borderlines of the Roman Monarchy, small States had thrived, such as the princes and leaders of Ghassan, to the west of the unproductive Syrian land, and the leaders of Hirah to which our poet Hassan ibn Thabit belongs, not too remote from the stream of Euphrates, reigned minor kingdoms, hearts of civilization that shed their enlightenment and knowledge farther than one would have thought. At Hirah, remarkably, where amalgam populaces are drawn from several countries had occupied.

One of the unique elements of Islamic poetry is that it depicts the communal and decent condition of the national culture of the Arabs before the advent of Islam.

The rise of Islam initiated a critical transition in Arabia from a primarily oral to a written culture. As this new civilization emerged, scholars became increasingly interested in the preservation of the Arabic language, the language of the Qur'ān, and the codification of Islamic history. In this context, they began to write down the wealth of poetry from the jāhilīya, which had previously been transmitted orally through narrators (Boutz, 2009, pp. 62-3).

Indeed, it is the Islamic Poetry that assists, provides, and serves as a gate through which one knows how to imagine the situation, whether it is honorable, ethical, or common, it is political or social, of the society of Islamic age. Besides, poetry was a means of defense as well as an attack against the enemies similar to the sword. It is sharp as the blade and too swift as the arrow in battle. The poet is a weighty figure in such a period. "For a poet was a defence to the honour of them all, a weapon to ward off insult from their good name, and a means of perpetuating their glorious deeds and of establishing their fame forever" (Hoyland, p. 212). Via the Arabic poetry of pre-Islam, reviewers, appraisers, and critics might recognize that Arabs, in a genealogical manner, were sometimes open-minded and in some other times, rigid lacking a chief government or power. The Arabs are fragmented into clans and tribes where the young are trained, taught, trained, and educated to be both warriors and poets.

Since the middle ages until the renaissance period and perchance after, with witnesses, evidence, verifications and justifications of Holy Mecca and Al-Medina El Monawara, Andalusia, Al Quaraouiyine Masjid of Morocco, Constantinople, Great Masjid of Kirwan in Tunisia, Baghdad of Iraq, Al Azhar of Cairo, Umayyad Masjid in Damascus, and many other shining examples and beacons of education, culture, erudition and knowledge in the Arabic Islamic world, Arab-Muslims led a real human civilization. The period of the Middle Ages, indeed, was of great worth. It saw significant development in several areas of scientific consideration. It is the role of the Arabs, who absorbed much of Greek sciences and learning that they acquired and reformulated the learned knowledge in Arabic formulas to be consistent with the human mind. Arab-Muslims worked hard in the process of translations. One of the essential sciences that took significant concerns is literature as a means of Man's knowledge. "The influence of literature among nations, from a country to another and from a continent to another, is tangible and palpable all over the ages. No one can deny the contribution and influence of Arabic and Islamic civilization on the West" (Dahami, 2017). This influence originated with the rise of Islam that saw light in Makkah (مكة) but steadily has expanded in Yathrib (يثرب), later called Al-Medina Al-Monawarah (المدينة المنورة), in which 
Hassan ibn Thabit accompanied the Prophet and amazingly produced the greatest of his elegant Arabic poetry in supporting of good against evil.

\section{Hassan ibn Thabit: Stately Poet}

It is in Medina that Hassan ibn Thabit flamed the torch of defense of the prophet and his message, Islam. Hassan ibn Thabit lived a lengthy life that exceeded a hundred years. The literary figure of this paper is Hassan ibn Thabit ibn Al-Munthir Al-Khazraji Al-Ansari of Bani An-Najjar, identified as the versifier of Prophet Mohammad along with the poet of Islam. Al-Khazraj, as a strong tribe of Yathrib, has preserved courtesy for their poet Hassan and valued his ability, talent, and faculty in protecting them. Hassan is famed by the name of 'the owner of the two lives' because, as a distinguished versifier, he lived with the great poets of pre-Islam along with those of the Islamic age (As-Safdi, 1987, p. 61). Even though his date of demise is given in a different way in the historical sources, we distinguish that he lived until the conclusion of the age of the caliphate Mouawiya. His long life is split into two equal parts in which he existed sixty years before Islam and the same years after. It is because of Hassan ibn Thabit and his poet-pioneers of Muslims that Islam had a dominant position. They defended Islam with the weapon of the word as the same as those who defended Islam with the sword. The need for Arabic poetry positively defending Islam had risen to a high degree. Hassan has dedicated his life to the most central matter in his life, the matter of the new religion that he involved, and clutched the flag of protection on his religion and his messenger, peace be upon him, and held the flag of lampooning the infidels, particularly after the Prophet declared to him: "lampoon and by word attack them; Jibril is supporting you" (A1 Ahdal, 1977, p. 161; Zabadi, 2006, p. 133; Ash-Shafa'i, 2012, p. 193; Ibn Saad, 2001, p. 325). The merit of Hassan ibn Thabit, the poet of Al-Ansar, goes back to the situation or locus that he is the initiator of the historical poetry chiefly the Islamic poetry; he has kept a record for his nation the names of combats and warfare between Muslims and polytheists, and the names of the companions, along with the names of the opponents and adversaries of Islam.

Sarcasm, satire, and lampoon have a substantial place in the Arabic language and literature with praise, in poetry. That is why defaming the Quraish poets led to the blame of the Quraish commune. Prophet Mohammad is conscious this veracity spoke to Hassan ibn Thabit: 'How are you going to reproach them, I am a man of Quraish just like them'. Hassan replied, 'I will remove you from the disbelievers of Quraish, just as you remove a bit of butter.'

\section{The Poem: Defending the Prophet Mohammad}

As I have mentioned in a previous paper on the same topic that the poem which is known as Al Alef rhymed (قافية الألف) needs further study, examination, and evaluation is focusing mostly on the language that Hassan ibn Thabit used in a very skilled and concise way. In this part, it is appreciated to attempt making a sort of fulfillment of the task because the verse of Hassan had a part that exceeds the role of the blade and spear. This part of the study starts with the verse line number seventeen as it is in his Diwan. 


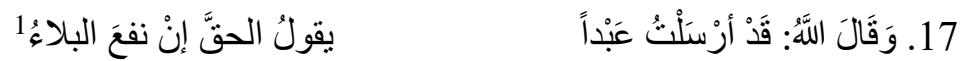

God said, 'I have sent a man who speaks the truth if you will profit by experience ${ }^{2}$

The above line shows the enormous influence of Hassan ibn Thabit by the Islamic culture and instructions, as well as in many of his poetry. The poet, in this verse line, confirms his belief that Allah sent a prophet messenger from among themselves - a human being; he is a slave worshiping Allah. The prophet never says nonsense, drivel, or twaddle. He speaks only the truth full of morality to the benefit of people because it is revealed by Allah.

The line, as well as most of his poetry, indicate the influence of Islam upon Hassan ibn Thabit. The following verses of the Holy Qur'an indicate such influence. "O mankind! Verily, there has come to you the Messenger (Muhammad صلى الله عليه وسلم) with the truth from your Lord. So, believe in him, it is better for you. But if you disbelieve, then certainly to Allah belongs all that is in the heavens and the earth. And Allah is Ever All-Knowing, AllWise" (Al-Hilali, 1419 A. H³ . p. 139, verse 170 Surat An-Nisa).

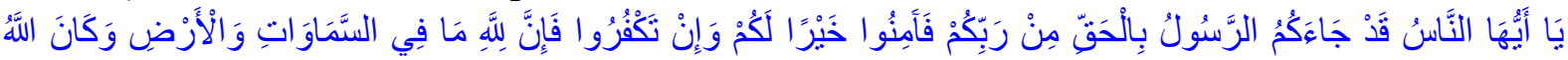
عَلِيمًا حَكِيمًا (170) (Al-Hilali, 1419 A. H. p. 139, verse 170 Surat An-Nisa). In another Surah of the Holy Qur'an, Allah says: "Verily We have sent you with the truth, a bearer of glad tidings and a warner. And there never was a nation but a warner has passed among them" (Al-Hilali, 1419 A. H. p. 584, verse 24 Surat Fatir).

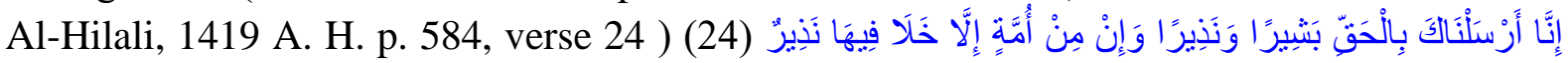

.(Surat Fatir

These are just only exampling out of several others that Hassan ibn Thabit employed in his poetry to follow the breaching of Islam. It is a palpable clue and witness of his experience, skillfulness, competence, dexterity, and power in the utility of the Arabic terminology.

$$
\begin{aligned}
& \text { فقلنم: لا نقومُ و لا نشاءُ }
\end{aligned}
$$

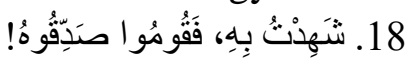

I bear witness to him, so arise and confess him truthfully. But you said, 'We will not, and we do not wish to' (p. 559).

The poet skillfully advises the disbelievers to listen and see the right path then follow; otherwise, the result will be devastating. Hassan invites the infidels to witness the truth of the message of the prophet; he tells them that he is a true believer of Allah and His messenger and prophet. Nevertheless, in vain, the poet, on their behalf, replies that the infidels prejudicially and arrogantly reject to follow the right light and path. They say that they will never believe or stand beside the prophet of Allah. The Arabic line is rich with assonance and consonance as it is the ingenuity and resourcefulness natural habit of the poet in dealing with broad, rich terminology.

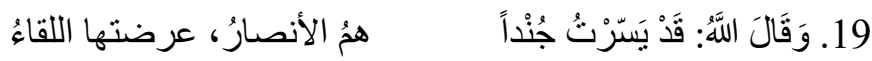

And God said, 'I have sent an army, The Ansar accustomed to the fray' (p. 559).

\footnotetext{
${ }^{1}$ Ibn Thabit, Hassan Al-Ansari. (1994). Diwan Hassan ibn Thabit. Interpreted by Abda' Mahana. Beirut: Dar Al Kotob Al Ilmiyah. p. 20. [All Arabic verses about the poem of Hassan ibn Thabit in this study are from this edition of the book unless otherwise mentioned, the number of the page is added to the verse line, pages 20-21].

2 Guillaume, A. (2004). The Life of Muhammad, a translation of Ibn Ishaq's Sirat Rasul Allah, Oxford: Oxford University Press. p. 558. [All English verses about the poem of Hassan ibn Thabit in this study are from this edition of the book unless otherwise mentioned, the number of the page is added to the verse line, pages 558559].

${ }^{3}$ After Hijra (travel) of Prophet Mohammad from Mecca to Madinah
} 
The poet Hassan ibn Thabit is one of Al Ansar who supported and sustained the prophet. The tribe of Al Ansar was a steady real victorious army. The poet confirms in this line that Allah has approved this army with blissfulness. They are called Al Ansar, and they are ready for battle. Allah praises Al Ansar in the Holy Qur'an: "And the foremost to embrace Islam of the Muhajirun (those who migrated from Makkah to Al-Madinah) and the Ansar (the citizens of Al-Madinah who helped and gave aid to the Muhajirun) and also those who followed them exactly (in Faith). Allah is well-pleased with them as they are well-pleased with Him. He has prepared for them Gardens under which rivers flow (Paradise), to dwell therein forever. That is the supreme success" (Al-Hilali, 1419, p. 262, verse 100, Surat At-Taubah).

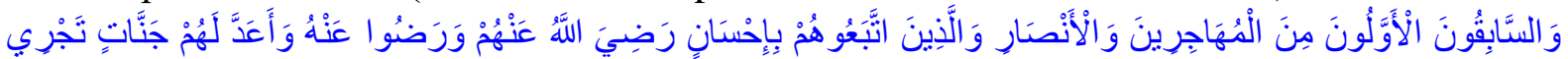

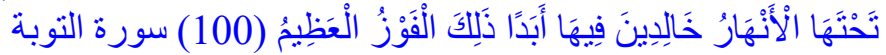

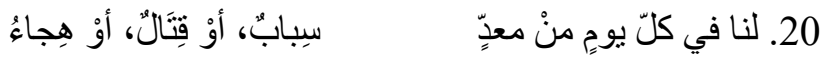

Every day we get from Ma'add cursing, battle, or lampooning (p. 559).

The poet in this verse line says that all their life is of great business, some of which are satirizing their enemies, fighting or lampooning them. Realizing the instructions and the teachings of Islam, the readers/critics need to understand that 'cursing, battle, or lampooning' come in accordance with Islam which means no aggression, violence, bellicosity, offensive nor tyranny, only defending themselves and their honor, esteem, and dignity.

A very distinguished word is $M a^{\prime} a d d$ (معد) which has broad and deep meanings. The linguists and polyglots say that the expression Ma'add (معدٍ) is masculine in which it is not ascribed to name any clan or tribe. It can be said that $M a^{\prime} a d d$ was not originally the name of a man (a proper noun) belonging to a particular tribe, but was a general expression involving several tribes that share a model of life, who are connected together in the line of descent. Hassan ibn Thabit used the word Ma'add (معد) representing Al Ansar (الانصار) stating that people of $A l$ Ansar have, in every day, either action against their enemies of a fight or a cursing or lampooning. Al Ansar supported the Messenger of Allah until they achieved victory (نصر) for that they were named Al Ansar.

He used the word Ma'add (معدٍ) in his poetry to denote opponents of Al Ansar, as used in exchange for certain tribes, and opponents of Al Ansar are disbelievers of Quraish. As the poet considers himself originally from Yemen, and the people of his town Al Madinah formerly known as Yathrib are of Yemeni origin, (Al-Awos and Al-Khazraj tribes; two central lineages living there) it is permissible to say: Hassan ibn Thabit expressed the idea of Ma'add and Qahtan in this time, and the opinion of the people of his town, especially in lineage when the emergence of Islam.

While Hassan ibn Thabit spends all his artistic poetry insulting the opponents of Al Ansar, the disbelievers of Mecca and defending the people of Yathrib, and the pride of his people over the people of $M a^{\prime} a d d$ and Nazar, we perceive that he does not mention those who accuse Adenians, and did not use in his poetry the name of Adnan, known in history that Adnan is the father of $M a^{\prime} a d d$ ? Furthermore, historians divided the Arabs into two origins: the origin of Qahtani and the origin of Adenani. It is found in the genealogy and history books the name of Adnan in advance of the $M a^{\prime} a d d$, and that the tribes of the Ma'add tribes call themselves Adenians and the Qahtan tribes consider themselves Qahtani. It can be said that Hassan may not have left Adnan and Adenians and resorted to the use of Ma'add if the expression Ma'add 
was not known and more familiar in his time. It is what we observe in all the remainders that go back to the period prior to Islam and after.

The expression 'Adnan', 'Adnaniya', and 'Adnanian tribes' has greatly emerged in Islam to the degree that it was not too famous before the advent of Islam. It is why the expression Ma'add, ma'adian, and ma'adian tribes. So, Adnan became a counterpart against Qahtan. Henceforth, the Arabs became either Qahtani or Adnanian; other associative expressions that were common in the period before the advent of Islam or the early days of Islam little by little disappeared

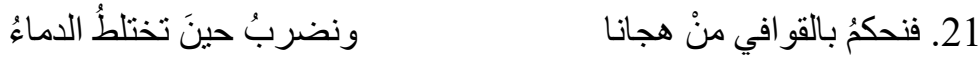

We will repulse with verses those who lampoon us, and smite them when war breaks out (p. 559).

In this verse line, the poet brings two amazing pictures; one is abstract, and the second is concrete. The first image that is drawn by the artist Hassan ibn Thabit is that one which deals with the ability to produce great influencing poetry. The poet states that he and the Muslimpoets have exceptional ability to satirically retort to the verse of infidels against the messenger of Allah. The poetry of Hassan, according to the above line, is concise and influencing. Its effect is exactly like the sword or blade in the battle. So, poetry is an effective weapon, but it is created for defense, not insulting others nor attacking others without reason. That is the first picture the poet created in this line.

The second portrait created by the poet is picturing the real battle between Muslims and their enemies. He draws an influencing image showing that the battle is severe, and the killed are too many but from the infidels. Hassan, in this line, puts the listener/reader in a scene where the Muslims control the situation, and they forcefully strike with their swords and steadily shoot their arrows and spears.

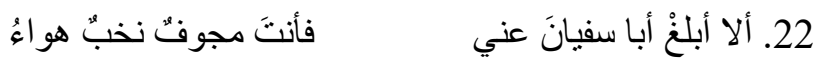

Convey a message to Abu Sufyan from me; you are just hollow like the useless wind.

The translation of this line by Guillaume (2004), does not match the Arabic line, so I tried a proper English translation for this verse line. The particular verse line is of considerable significance in which it is the core of the entire poem. It dealt with a definite person and forwarded toward Abu Sufyan (also can be written as Sofyan and Sufiyan), who wrote a poem lampooning the prophet and Islam. As I have said earlier, this poem, in general, is a defense of the prophet and a showing of some moral qualities of Islam. Hassan addresses Abu Sufyan in a challenging manner, saying that any person listening to me he is a messenger to inform Abu Sufyan that he is just a hollow, vacant, and insincere person who has nothing inside him. He is without substance. Here is a direct lampooning against Abu Sufyan, repaying him with strong attacking expressions. Sometimes the word is sharper and snappier than a real weapon. The poet speaks to Abu Sufyan, stating he is not only wind, but he is a muddy wind. A great picture the poet brings to the listeners is conceived through the use of personification when he applied the expression nakhbun hawao (نخبُّ هو اءُ). The idea in the second hemistich indicated that the wind incarnated in Abu Sufyan is that the coward has no heart or emotion.

Who is Abu Sufyan mentioned in this poem who is characterized by language eloquence and derived in many of the content of the Qur'an? He is Abu Sufyan ibn Al-Harith ibn Abdul Muttalib, not Abu Sufyan ibn Harb ibn Umaiyah. He is a cousin of the Prophet Muhammad; 
peace be upon him. Abu Sofian ibn Al-Harith was a poet, and the Prophet Muhammad was lampooned, and the Prophet wasted his blood. Hassan ibn Thabit has only to defend the Prophet with the same weapon used by Abu Sofian, the weapon of the word, which is considered to be sharper and more effective for Arabs who know the meaning and connotation of its utility.

Historians tell us that Abu Sufyan wanted to convert to Islam before the conquest of Mecca, but he could not go directly to the Prophet. He, instead, met his cousin Ali ibn Abi Talib to consult him and take the advice from the one whom Abu Sufyan knows his knowledge, understanding, sincerity, and honesty in opinion and advice. Ali, may Allah be pleased with him, advised his cousin Abu Sufyan ibn Al-Harith to go to the Prophet and apologize to him

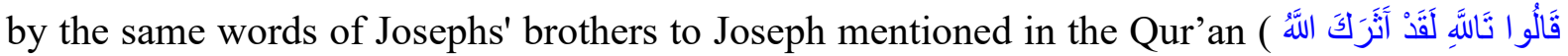
( عَلَنْنَا وَإِنْ كُنَّا لَخَاطِينينَ (They said: By Allah! Indeed, Allah has preferred you above us, and we certainly have been sinners" (Al-Hilali, 1419 A. H., p. 316). Of course, this apology is an apology taken from the Qur'an and indicates an excellent acumen of Ali Ibn Abi Talib.

What was the intention of Ali with this apology? A number of critics and psychologists say that the human soul - any human soul - has a key to the heart and that the person should better choose the right and appropriate key. Prophet Muhammad, peace be upon him, is the most honored human to Allah. The Prophet was directed by Allah to make the antecedent prophets his example in the guidance and tutelage; he is a follower of them where the

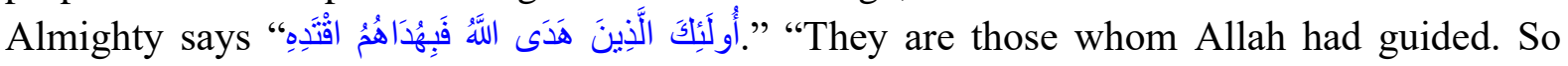
follow their guidance" (Al-Hilali, 1419 A. H., p. 183). Mohammed excerpted and had been enlightened by the guidance of the ancestor prophets, in which Allah has augmented him with guidance more comprehensive than what has bestowed to the ancestor prophets. Muhammad thus exceeded all the ancestor prophets and messengers.

In a situation like this appears the wisdom and acumen of Ali ibn Abi Talib, may Allah be pleased with him, who guided Abu Sufyan to the best ways to receive the pardon and forgiveness of the Prophet. It can be said that, in advising his cousin Abu Sufyan, Ali wanted to say as Joseph's brothers said to their brother, Joseph (Yusuf) peace be upon him, apologizing, "Allah has preferred you above us, and we certainly have been sinners" (AlHilali, 1419 A. H., p. 316). In doing so, Abu Sufyan comes up with the sympathy and forgiveness of Prophet Muhammad. As he is aware that the Prophet does not like others to be better than him in goodness, it is human nature in everyone; how the matter is with a prophet. The perception and acumen of Ali ibn Abi Talib indicate that the Prophet does not want Yusuf (peace be upon him) to be better than him in goodness, and therefore will forgive Abu Sufyan. The advice of Ali, may Allah be pleased with him, has come true in which Abu Sufyan came to the Prophet telling him what Ali mentioned to Abu Sufyan to do, then the Prophet exempted Abu Sufyan from punishment.

Abu Sofian ibn Al-Harith has benefited from the advice of Ali ibn Abi Talib, may Allah bless him, as Abu Sufyan in the battle of Hunain, came to the Prophet and grabbed the mule that the Messenger of Allah was riding. The Prophet said to him "who are you', not recognizing Abu Sofian because of the terseness of the battle with the infidels. 'I am the son of your mother, O Messenger of Allah,' “انا ابن أمك يا رسول الله” (Ar-Roiani, 2016, p. 122; Al Khazen, 2015, p. 153; Ash-Shaibani, 2003, p. 82), replied Abu Sufiyan, as a metaphor for the brotherhood, although Muhammad does not have brothers, males or females. The connotation 
here refers to the advantage of Abu Sofian as opined by Ali, where Abu Sofian wanted to be guided by the dialogue that took place between the prophetic brothers Moses and Aaron, as revealed in Surat Ta-Ha When Moses censured Aaron because Aaron did not stand against the wrongdoings and deviations of his clan, the Israelis at the time of Moses' absence to meet his Lord, Allah. It is evident in this context that Aaron wanted to propitiate and placate his

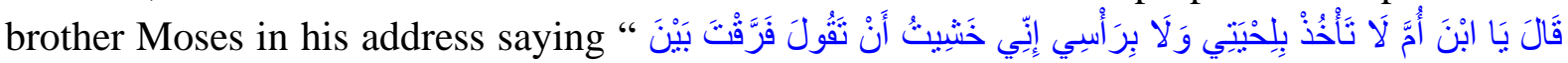

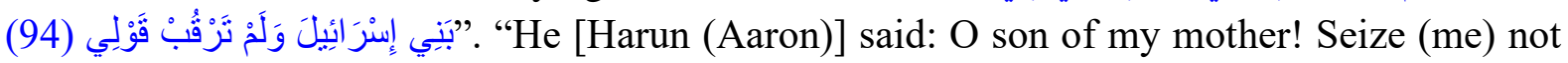
by my beard, nor by my head! Verily, I feared lest you should say: 'You have caused a division among the children of Israel, and you have not respected my word!"” (Al-Hilali, 1419 A. H., p. 423). It is agreed that the link of kinship from the mother's side is one of the most reliable links.

Abba Sufyan was sincere when he wanted to make it clear to the Prophet that he is his brother; Arabs often use metaphors and puns in talking and speech because of their stronger influence on the listener. Indeed, Abu Sofian is the brother of the Prophet Muhammad who is breastfeeding, and Abu Sofian did not want to tell him that 'I am your cousin' openly. Still, he used a formula soft, friendly, and closer to the heart. It was the intention of Abu Sufyan to remind the Prophet of the days of breastfeeding as boys from Halima Saadia. Abu Sufyan, in this context, wanted to prove the incident and take appropriate words, as is the custom of the Arabs in the use of classical Arabic in its profound connotations, and a way to the heart of the Prophet, and thus choose the words that perform the purpose and gain the love of the Prophet and then the love of people. Muhammad, peace be upon him, is an open book and has a fragrant career. He is a man of great virtues and praise.

The witness here is the wonderful and distinctive linguistic use of Arabic language poetry and prose; the fresh and sweet words have their impact on the mind and heart before the ear. The beauty of the Arabic language is obvious for that it can bestow its owner a positive attitude and save him in stressful situations. The speaker, the skillful of the classical Arabic language, can win and obtain the kindness of others without losing substantial of his dignity, worth, and pride creation.

\section{Discussion}

The poet, Hassan ibn Thabit, has revealed a true and honest sarcasm, sendup satire, and lampooning against the disbelievers of Quraish without exaggeration or hyperbole. He systematized his poetry, not for the purpose of earning of getting benefits or profits but defending the values, ethics, and principles of his creed - Islam. His poems are a defense of the prophet and his message trusting to get the satisfaction, gratification, and contentment of Allah.

This poem, titled Al Alef Rhymed, is one of the diplomatic, political, and constitutional poetry for Hassan ibn Thabit. In it, the poet has exercised the power of the expression as a weapon of shielding, securing and defending the prophet and Islam from infidels. It is a famous and legendary piece of poetry versified during the first decades of Islam principally after the hijra of the prophet from Makkah to Madinah in which the skirmish was critical between Muslims and the infidels of Quraish.

\section{CONCLUSION}

The paper expected at analyzing and inspecting the symbolic, rhetorical, and aesthetic images in the poem of Hassan ibn Thabit. As the study shows, it pursued the obvious logical method 
focused on the most significant sources. This example of Arabic poetry portrays and reveals original Arab ideals, models, principles, and standards in the Arabic poetry of the Islamic age. The researcher could state that the task attained certain concerns, the most noteworthy of which is the impact of Arabic graceful tongue.

The Arabic tongue is presented as the precision and superiority of phraseology and full with sparks of wit and ritual. "The Arabic language is characterized by accuracy, precision, and accurateness regarding expressions and its arrangements" (Dahami, 2018b). Generally, the poem of Hassan ibn Thabit can be valued as one of the thoughtful pieces of the poetry of Arabic principle and convention, for it contains Arabic heritage of the classical poetic language. 'Al Alef rhymed (قافية الألف)'poem had been revealed as a work of wonder and marvel. Hassan ibn Thabit by composing this piece of poetry, succeeded in conveying an Arabic harmonic essence through his opulent terminology. He could produce intelligence of outstanding moods and elicit the tensions of inspiring elements. Al Alef rhymed (قافية الألف)' poem, thus, is a significant specimen of Arabic poetic tongue. It is one of the poetic magnum opuses to have made a tangible effect among Arab people in the time of its composing and today.

As a suggestion, the researcher suggests in further studies and investigations to fulfill the rest of the poem that deals with poetic reliefs and reinforcements as well as artistic potentials, values, and emblematic prophecies. What has been declared in this brief study, might be insufficient to entirely satisfy the intent of searching the density of work like 'Al Alef rhymed (قافية الألف)' poem. It is praiseworthy of further researching.

\section{References}

Al Ahdal, M. A. S. (1977). Poetry in Light of the Islamic Legislation. Madinah: Al-Islamiyah University.

Al-Hashimi. A. (1969). Jawahir Al-Adab fi Adbiat wa Insha Lughat Al-Arab (Jewelry of Literature in Literatures and Growth of the Language of Arabs) Vol. 2; 27 $7^{\text {th }}$ Edition, Egypt: Al-Maktabah At-Tejariah Al-Kubra.

Al-Hilali, M. T. (1419 A. H.). Khan, M. M. The Noble Qur'an: English Translation of the Meanings and Commentary, Madinah: King Fahd Complex for the Printing of the Holy Qur'an.

Al Khazen, A. M. A. (2015). Alruwd Walhadayiq fi Tahthib Sirat Khayr Alkhalayiq (Vol. 3), Beirut: Dar Al Kotob Al Ilmiyah.

Allen, R. (2000). An Introduction to Arabic Literature. Cambridge: Cambridge University Press.

Ar-Roiani, A. M. H. (2016). The Predicate of the Companions (Known as The Predicate of Ar-Roiani) Musnad As-Sahabah. Beirut: Dar Al Kotob Al Ilmiyah.

Ash-Shafa'i, A. M. E. M. N. (2012). Al-Awsad fi As-Sunan wa Al-Ejma'wa Al-Ekhtelaf (The Medium in Sunnah, Agreements and Difference, part 4. Beirut: Dar Al Kotob Al Ilmiyah.

Ash-Shaibani, A. A. A. (2003). The Singles and the Duos (Alahad Walmathani). Beirut: Dar Al Kotob Al Ilmiyah.

As-Safdi, S. K. (1987). Meadows of alliteration and Creativity. Beirut: Dar Al Kotob Al Ilmiyah. 
Boutz, J. H. (2009). Hassan ibn Thabit, a True Mukhadram: A Study of the Ghassanid Odes of Hassan ibn Thabit, (Ph. D. Thesis), Georgetown University, Washington.

Dahami, Y. S. H. (2019a). Mua'llaqah of A'mru ibn Kolthoum: A Representative of the Greatness of Arabic, Advances in Language and Literary Studies (ALLS), 10(1), 7785.

Dahami, Y. S. H. (2019b). Influence of the Arabic Language: The Muwashshah of ibn Sahl Al-Andalusi an Example. American Journal of Humanities and Social Sciences Research (AJHSSR), 3(1), 58-65.

Dahami, Y. S. H. (2018a). The Arabic Tongue: A Worthy Language, European Journal of Language and Literature Studies, 4(4), 81-90.

Dahami, Y. S. H. (2018b). Voice of Arabs Taabbata-Sharran: A Bandit by Name a Poet of Pride, International Journal of Science and Research (IJSR), Vol. 8(2); pp. 23032310.

Dahami, Y. S. H. (2017). James E. Flecker's Poetic Play "Hassan": The Arab Influence, Aljouf University Social Sciences Journal (AUSSJ), 3(2), 117-129.

Dahami, Y. S. H. (2015). The Contribution of Arab Muslims to the Provencal Lyrical Poetry: The Troubadours in the Twelfth Century. Journal of Arts, 27(1), 1-19.

Faheem, H. (1986). The Story of Anthropology: Chapters in the History of Human Science. Kuwait: The National Council for Culture, Arts and Literature.

Gruendler, B. (2002). Medieval Arabic Praise Poetry: Ibn Al-Rumi and the Patron's Redemption. Routledge, retrieved on 2018-10-11 from https://ebookcentral-proquestcom.sdl.idm.oclc.org

Guillaume, A. (2004). The Life of Muhammad, a translation of Ibn Ishaq's Sirat Rasul Allah. Oxford: Oxford University Press.

Hitti, P. K. (1989). History of the Arabs: from the Earliest Times to the Present. $12^{\text {th }}$ reprint, London: Macmillan \& Co. Ltd.

Hoyland, R. G. (2001). Arabia and the Arabs: From the Bronze Age to the Coming of Islam. London and New York: Routledge.

Ibn Khaldoun (1958). The Mugaddimah: An Introduction to History, in three volumes. (Translation: Franz Rosenthal). New York: Princeton University Press.

Ibn Saad, (2001). Kitab At-Tabagat Al-Kabeer (The Book of Big Layers). Part 4. Cairo: International Company for Printing.

Ibn Thabit, Hassan Al-Ansari. (1994). Diwan Hassan ibn Thabit. Interpreted by Abda' Mahana. Beirut: Dar Al Kotob Al Ilmiyah.

Lewis, B. (2002). The Arabs in History. Oxford: Oxford University Press.

Mou'nis, H. (1978). The Civilization: A Study in the Basis and Factors of its Origination and Development. Kuwait: The National Council for Culture, Arts and Literature.

Seignobos, C. (1912). History of Ancient Civilization. New York: Charles Scribner's Sons.

Thaif, S. (1960). History of Arabic Literature: Ignorance Age. Cairo: Dar Al-Ma'arif of Egypt.

Zabadi, T. A. (2006). The Approach of the Holy Qur'an in Praising the Oligarchy and Denigrating the Mass. Beirut: Dar Al Kotob Al Ilmiyah. 